\title{
Petrography and Mineralography of Emarat Lead and Zinc Deposit (South Arak)
}

\author{
Safoura Khani ${ }^{*}$, Ahamd Khakzad ${ }^{2}$, Mehdi Safari ${ }^{3}$, Ali Solgi ${ }^{1}$ \\ ${ }^{1}$ Department of Geology, Sciences and Research Branch, Islamic Azad University, Tehran, Iran \\ ${ }^{2}$ Department of Geology, North Tehran Branch, Islamic Azad University, Tehran, Iran \\ ${ }^{3}$ Departement of Geology, Payam Noor University, Arak Branch, Arak, Iran \\ Email: *Skhani.1986@gmail.com
}

Received 24 February 2016; accepted 19 June 2016; published 22 June 2016

Copyright (C) 2016 by authors and Scientific Research Publishing Inc.

This work is licensed under the Creative Commons Attribution International License (CC BY). http://creativecommons.org/licenses/by/4.0/

(c) (i) Open Access

\begin{abstract}
Iran is host to more than 285 zinc and lead carbonated host deposits including world-class deposits such as Mehdi Abad and Irankouh. Emarat deposit is located in Sanandaj-Sirjan zone and Malayer-Isfahan metallogenic province (northwestern part of Sanandaj-Sirjan tectonic zone). In the area, the mineralization has stratabound shape and restricted to Early Cretaceous limestones and dolomites. With investigation of the optical properties in microscopic survey and evaluation results of analysis, sphalerite, galena, pyrite and chalcopyrite were recognized as the main minerals, covellite, tennantite-tetrahydrite and serosities, quartz and barite as the secondary minerals and gyps, smithsonite were recognized as the minorminerals in the samples. Silicification alteration acted as major process in studied deposit and dolomitization, pyritization and hematitization also were observed in the deposit. Evidences show that mineralization has occurred in post diagenetic stage (epigenetic type) and after tectonic influence.
\end{abstract}

\section{Keywords}

Carbonated Host Deposits, Mehdi Abad, Irankouh, Silicification, Alteration, Diagenetic Stage

\section{Introduction}

Iran, given the appropriate geodynamic conditions, has widespread areas of high potential for zinc-lead carbonated host deposits or large carbonated platforms. More than 285 carbonated host deposits exist in Iran, including world-class deposits such as Mehdi Abad and Irankouh.

Nevertheless only limited number of them have been extracted and exploited. Cretaceous carbonates often

${ }^{*}$ Corresponding author.

How to cite this paper: Khani, S., Khakzad, A., Safari, M. and Solgi, A. (2016) Petrography and Mineralography of Emarat Lead and Zinc Deposit (South Arak). Open Journal of Geology, 6, 387-398. http://dx.doi.org/10.4236/ojg.2016.66034 
constitute the host rock of such deposits, mainly localized on the metallogenic belt of Malayer-Isfahan, Yazd-Anarak, and to a lesser extent, in central Iran and central Alborz metallogenetic belt [15]. There is no common consensus on the classification of MVT deposits hosted by Cretaceous carbonate rocks, especially in SanandajSirjanzone. Some authors consider them as exhalative deposits [12] but the recent studies [4] [7] have attributed them to MVT deposits. Most of these deposits have been formed near the opening of northern Paleotethys of Iran, showing a close relationship with the crustal tectonic events [16]. Most of the previous authors [4] [7] have suggested that lead and zinc mineralization in Cretaceous carbonate sequence has occurred in connection with the collision of the Arabian plate with the Sanandaj-Sirjan zone, followed by the closure of the Neotethys ocean.

Emarat deposit geologically and structurally belongs to Sanandaj-Sirjan zone and locates in Malayer-Isfahan metallogenic province (northwestern part of Sanandaj-Sirjan tectonic zone) (Figure 1). This deposit lies in the western part of central Iran and 50 kilometers southwest of Arak City and 30 km off West Khomein City. Emarat deposit with 5.12 million tons proved reserves and average grade of 5\% zinc and $2 \%$ lead, now in operation with annually extraction capacity of 90,000 tons of mineral from the endogenous part [5] is considered the largest and most significant zinc and lead deposit in the south Arak mineral zone located in the middle part of Malayer-Isfahan belt.

\section{Geologic Settings}

Sanandaj-Sirjan zone is basically part of central Iran, featuring special characteristics and lying as a long metamorphosed strip along and parallel with Zagros overthrusting. Northern boundary of the zone with central Iran

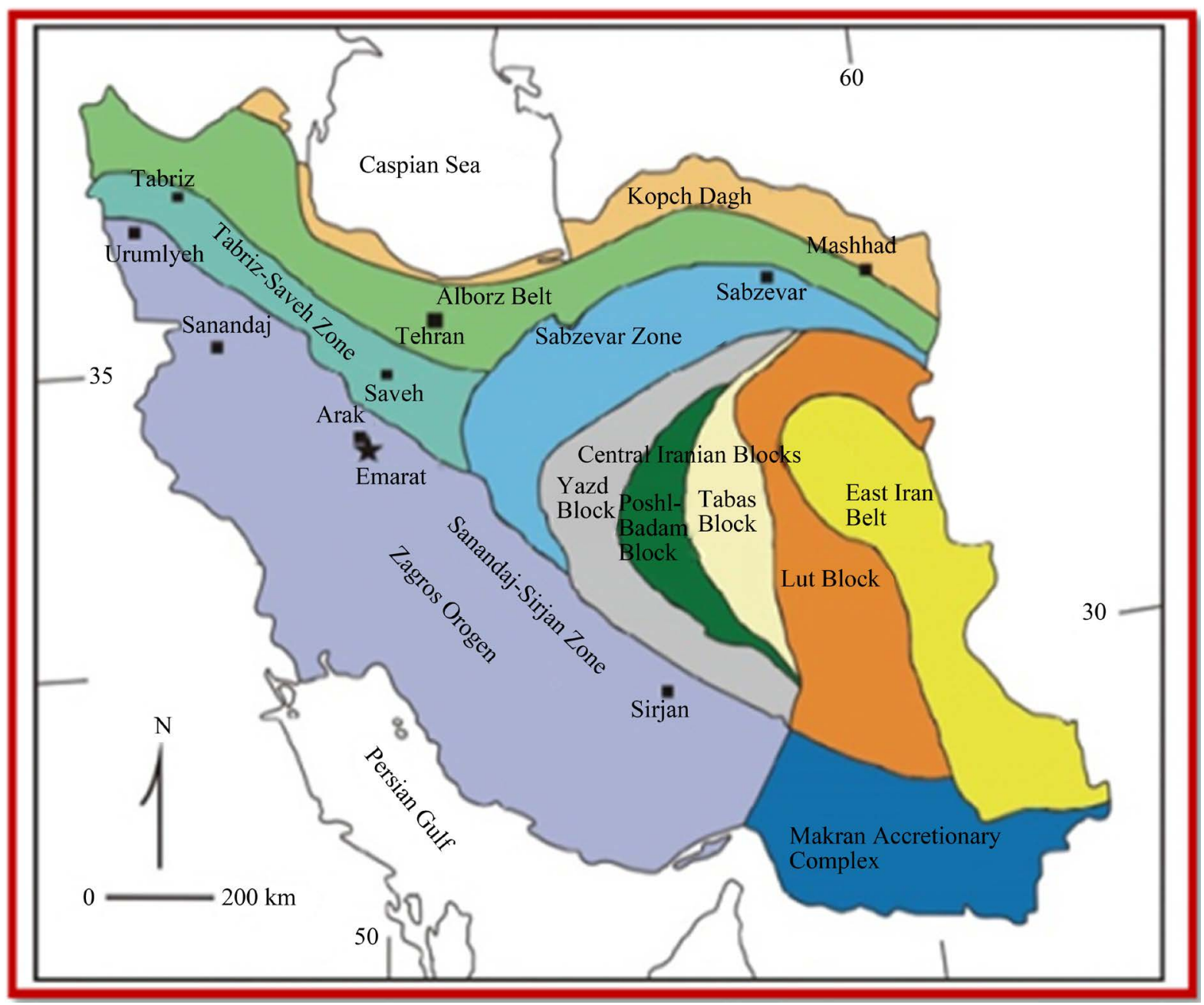

Figure 1. Main structural zones of Iran (updated from [2]) and Emarat mine. 
passes through Quaternary alluvial plains and elongated depressions along the Zagros trend like Sirjan-Gavkhoony and Arak depression [10]. Schtoklin has introduced Sanandaj-Sirjan zone as a structural unit for the first time among the structural zones of Iran.He proposed the Mesozoic metamorphic phases as the factor involved in metamorphism of Sanandaj-Sirjan and central Iran [18]. Malayer-Isfahan metallogenic zone which is mainly host for stratabound lead and zinc deposits with sedimentary host is located in the middle part of Sanandaj-Sirjan zone. The general trend of the zone corresponds to the northwest-southeast Zagros trend with an area of about 30,000 $\mathrm{m}^{2}$ [14]. This strip is known as one of the lead and zinc mineral areas of Iran [15] and is host for multitude number of deposits and lead-zinc mineral signs like Ahangaran [11], Irankouh [7], Ravanj [3] and Robat [1]. Emarat region is part of northwestern geologic map of Golpaygan with 1:250,000 scale (Figure 2).

Based on Golpayegan geological map [19] the oldest outcropped stratigraphic unit in the southern Arak mineral zone is the Jurassic (Js) era dark-colored shale with sandstone interlayers, severely folded as the result of middle Cimmerian orogenic phase and covered by lower Cretaceous progressive sediments after a prolonged period of erosion [2] Lower Cretaceous sediments include conglomerates, sandstone and sand-lime rocks (kc). An ensemble of thin layered sheet limestones, shale and lime-marl stones $(\mathrm{km})$ covers the mentioned sediments which are gradually converted into thick layered lime stones $(\mathrm{kl})$ through time. The $\mathrm{Kl}$ section includes thick layered to mass limestone containing Orbitolina, Crinoidea, Bivalve fragmentals and algae traces that has been formed in a shallow environment [13]. This section which is host to lead and zinc mineralization has undergone alterations from petrification stage like dissolution and re-deposition of carbonates along failures and joints and sometimes regional very weak metamorphism which is manifested by re-crystallization of calcite and blurred schistosity areas [14]; it has been covered by an ensemble of Apsian aged thin layered limestones (Ks), shale and marl and Albin aged Orbitolinlimestones (Klu). Cretaceous stratigraphic rock units have been highly faulted and folded as a result of Laramian and Alpine orogenic movements [17] [19].

Emarat deposit lies on the northern limb of a reversed syncline of $5.1 \mathrm{~km}$ length and 500 meters width [10],

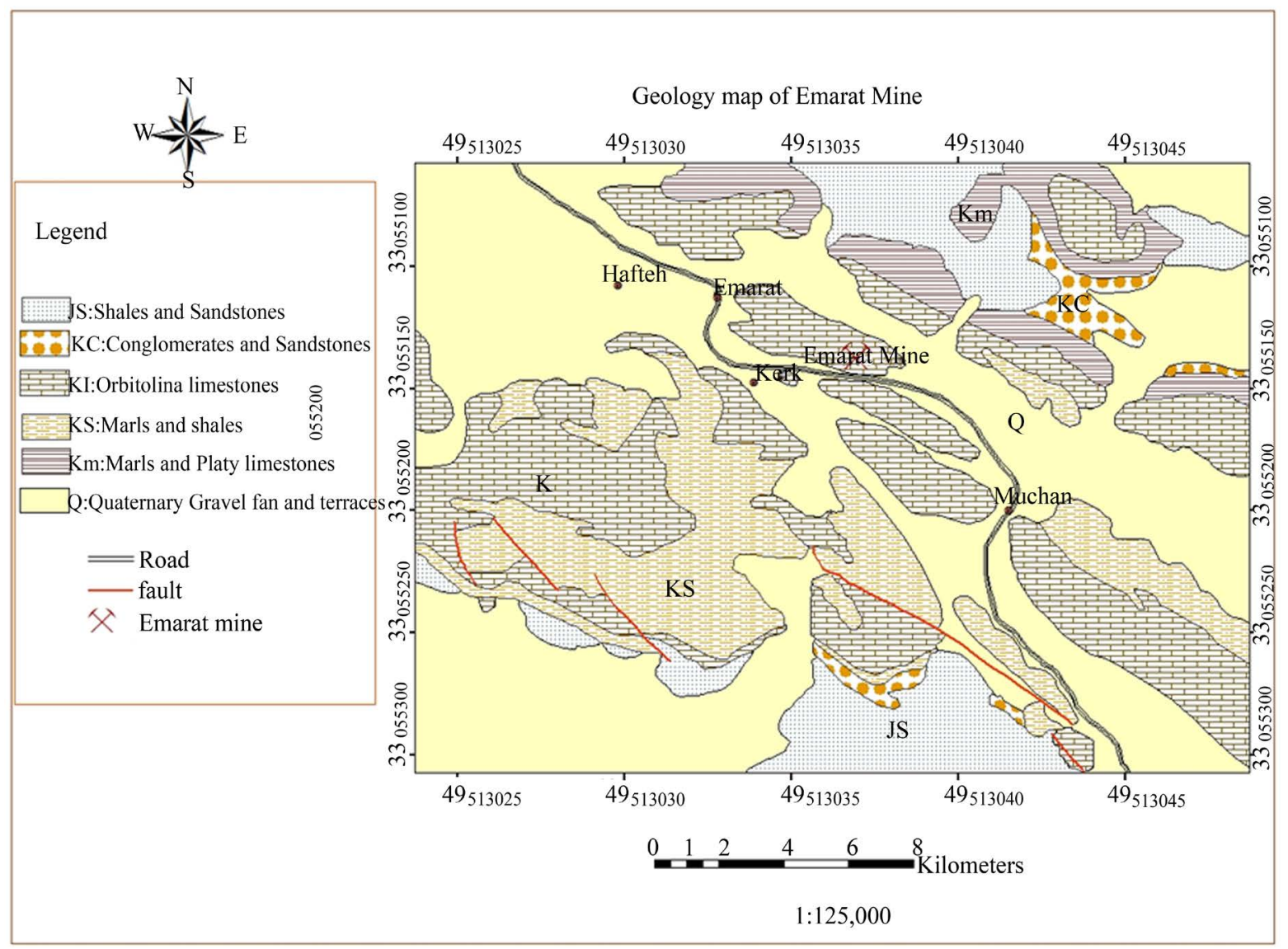

Figure 2. Geologic map of South Arak mineral zone, taken from the map base [19]. 
hosted in thick layered to mass limestones of Kl section (Figure 3). Dark grey Orbitholin contained limestones of $\mathrm{K} 1$ section are categorized in bio-micritic lime group. The mineral mass typically takes the form of a plain with about 3 meters thick, although small scale folds have caused higher thicknesses locally. Contact between mineral mass and host rocks is often sharp, but diffusion contacts are also found sometimes in footwall limestones [4]. Numerous faults parallel with the syncline axis can be seen which cause dissection and displacement of the mineral material [4]. The direction of faults and layers is northeastward-southeastward and the layers are slopped northeastward with an angle of approx. $650^{\circ}-800^{\circ}$ [8]. In Emarat deposit area, some very weak regional metamorphism is observed in lower Cretaceous sedimentary rocks' sequence (including mineral hosted rocks) which result from Laramianorogenic phase in upper Cretaceous era [18]. Minor effects have been resulted from such metamorphic developments including weak to good orientation of some rocks' texture, stretching, ellipticity and widening of rock minerals, deformed fossils, ductility of layers especially in shales, and recrystallization [8] [20].

Emarat deposit zone is almost free from volcanic rocks. The only volcanic rocks which is observable only within $12 \mathrm{~km}$ off Emarat deposit locates in the vicinity of Shams-Abad manganese iron ore mine, mainly including lower Cretaceous aged andesitic rocks.The closest sedimentary rocks to Emarat deposit includes two groups of such rocks: 1) upper Cretaceous aged plutonic masses constituting from granite, granodiorite and diuretic quartz stones (Asatneh granite) [17] located in direct distance of approx. 25 km west of Emarat deposit; 2) post lower Cretaceous aged plutonic masses including monzogabbro and monzodioritestones [13] located at about a direct distance of $25 \mathrm{~km}$ north of Emarat deposit.

\section{Materials and Methods}

Using field observations and microscopic studies, shape of the minerals, their relationship and also the metasomatism and solid solution effects on the deposit range stones as well as the texture and structure, relationship between minerals, and the relationship of phenomena and deposit genesis were be evaluated. To achieve this goal, sampling was performed from Emarat deposit mineral vein and from the host rock and in total 10 polished samples and 14 thin sections were prepared and examined using microscope; also 4 XRD analysis were carried out for identification of mineral types.

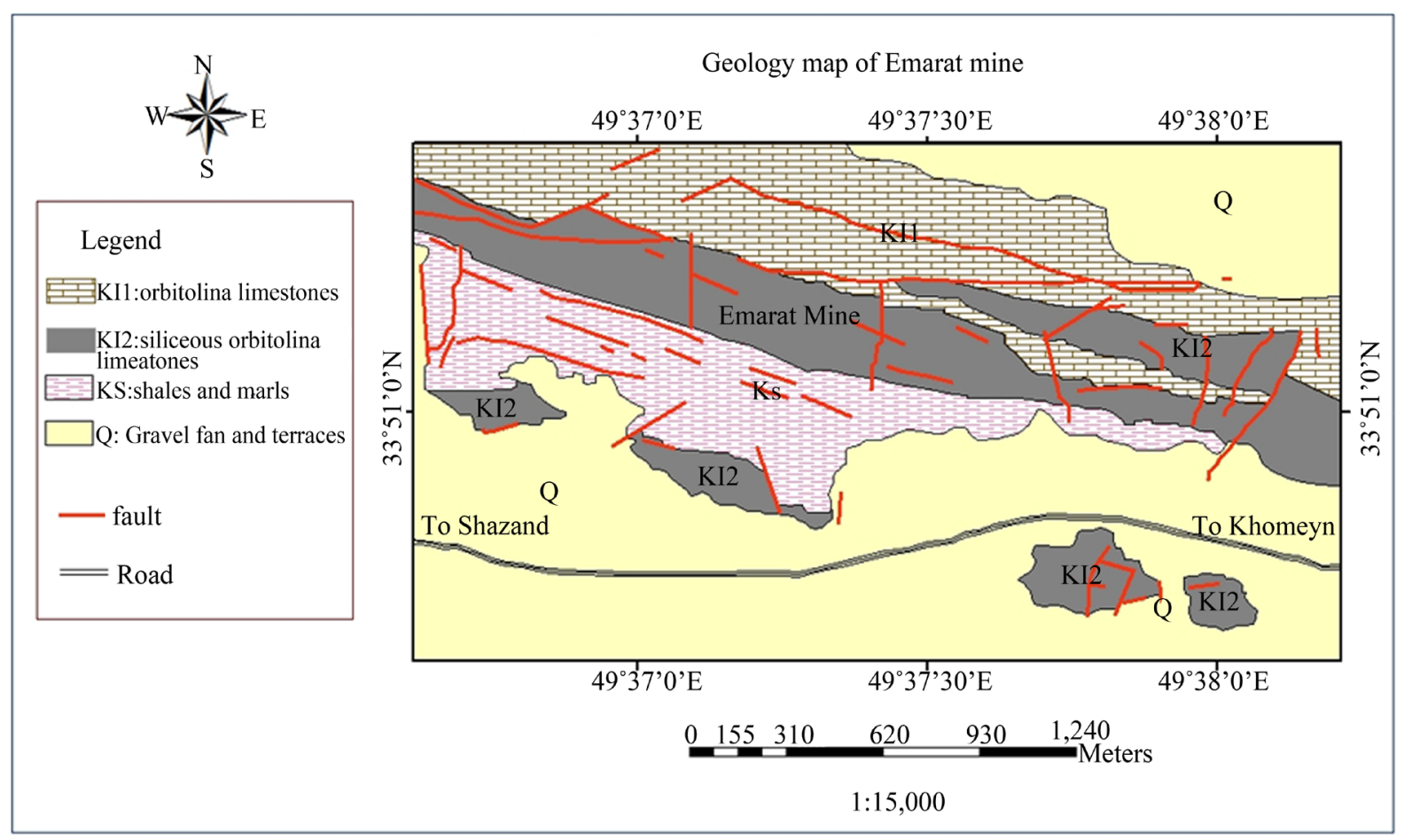

Figure 3. Geologic (modified) map of Emarat deposit range [5] [6]. 


\section{Most Important Alteration Processes in the Host Rock (Early Cretaceous Deposits)}

Detailed observation and analyses in Emarat deposit have led to identification Four types of alteration (silicification, dolomitization, pyritization, hematitization that (will be evaluated in the ongoing parts).

Macroscopic silicification was observed in Emarat deposit in the above mentioned sections. Given that mineralization has taken place in Orbitolin contained dark grey thick layered to mass limestones of K1 section [9], silicification of limestone was divided into two lower K11 and upper K12 sub-divisions, with k12 having undergone silicification alteration process so that proximity to KS shale and marlpart reveals higher silicification intensity. Although silicification alteration is regarded an unusual kind of alteration in most Mississippi type lead and zinc deposits [15] but it is considered a major alteration in Emarat deposit and as was mentioned above, it lies on upper part of limestones of K1 section (Figure 4). In previous studies [6] silicification in Emarat deposit has occurred in two stages: The first stage includes fine crystalline quartz heavily replacing the carbonated host rock and the second stage constitutes from quartz veins and veinlets of $1 \mathrm{~mm}$ to $5.1 \mathrm{~m}$ thick crosscutting the silified host rock, also evidenced by microscopic observations. The quartz crystals have been created in the rock in 3 generations: 1) the primary Mono-Crystalline quartz, constituting the matrix rock; 2) Poly-Crystalline quartz which is the result of re-crystallization after diagenesis. These two quartz silicification alteration have occurred in the first stage. 3) Quartz veinlet (Figure 6(a)) that has been injected into the rock and has crosscuted the host rock, containing two types of veins in some sections: (a elongated threadlike crystals type and b) re-crystallized silified veinlet Figure 6(b) having been formed during the second stage of alteration (Figure 4).

Silicification of limestones can take place as a result of carbonate dissolution and simultaneous settlement of silica in the rock body, like silicification of the first stage, filling of open spaces and failures with silica, like the second stage of silicification, or a combination of both events.

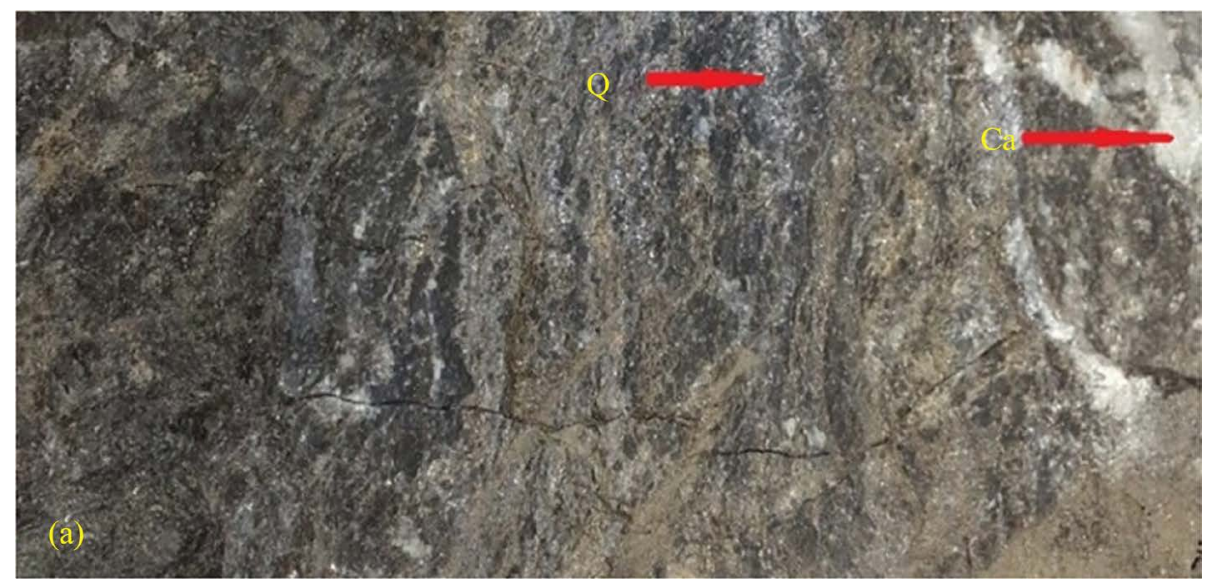

(a)

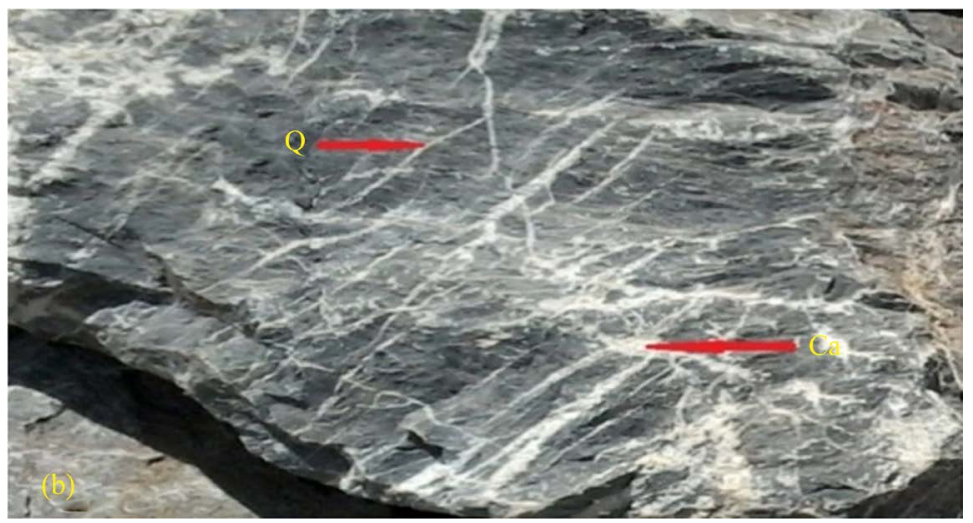

Figure 4. (a) Silifide limestone in the high grade part of Emarat deposit ore; (b) A view of Emarat ore deposit with calcite and quartz veinlets. 
Dolomitic alteration was less observed in the sections compared with other alteration types; smaller areas of this kind of alteration can be found in the area with unspecified traces due to prevalence of silicification alteration in the area.It seems like this alteration has occurred before silicification alteration [8]. Macroscopic hematitization alteration was also observed in sections of the deposit (Figure 5).

\section{Mineralization}

Considering the microscopic studies and field observations the most important texture and structure observed in Emarat deposit were as follows: disseminate, replacement, fine-grained, open-space (breakage and faults) filling, vein and veinlets. Part of the minerals in this deposit have occurred among smaller synclines and anticlines located within larger synclines and anticlines of the area; they only fill the spaces between the axes and no relationship can be found between such structures and mineralization, showing that mineralization has occurred before development of such synclines and anticlines [17]. All the evidences indicate that Emarat deposit is of Mississippi type deposits.The deposit range has carbonated host rock including quartz, calcite, clay minerals, and dolomite to a lesser extent that have undergone intensive diagenetic and tectonic processes. Jurassic shales constitute the host rock of Emarat deposit and the sculpture part has formed in this rock unit. The shales content would increase by moving towards the shales Given the existing evidences it can be said that mineralization has occurred in post diagenetic stage and after tectonic influence and is of epigenetic type.
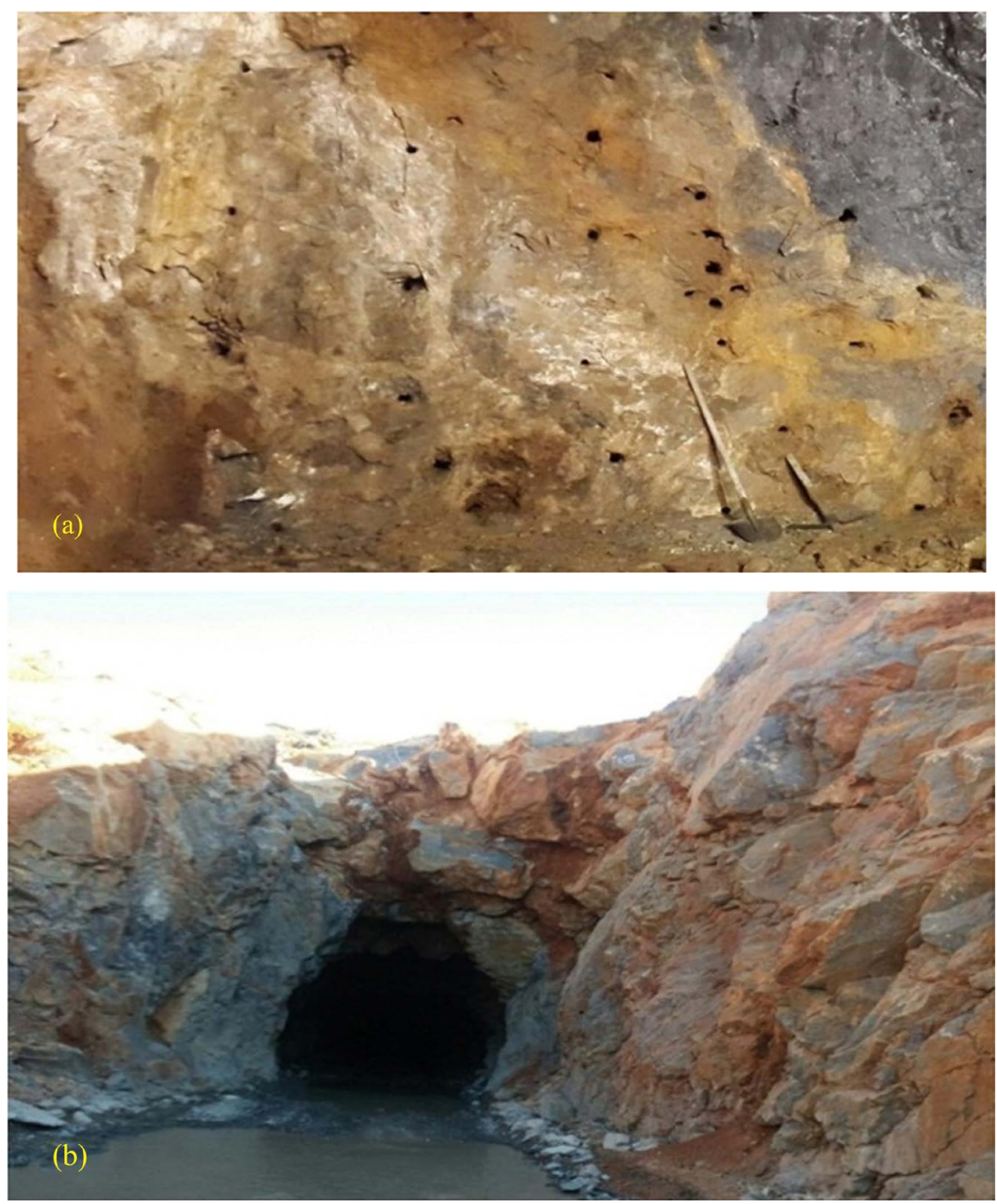

Figure 5. (a) Iron oxides in the high grade parts of Emarat deposit; (b) Iron oxides in a view of exploitation tunnel in Emarat deposit. 
Considering the field evidences, mineralogical and structural studies the paragenetic sequence in this deposit includes 3 pre-mineralization stage, main stage and post-mineralization stage. Pre-mineralization stage is determined by the presence of calcite, dolomite and quartz in the limestone host. The main stage can be specified by the presence of sulfide, sphalerite, galena, pyrite and chalcopyrite minerals.The post-mineralization stage is specified by the secondary minerals like covellite, chalcocite, tennantite-tetrahidrite, iron oxides, smithsonite and barite. Sphalerite is the main the most abundant metal mineral of Emarat deposit having been formed in two stages considering the evidences found in the sections.Some of the sphalerite, considering the intergrowth with the host rock minerals has become crystalized before main mineralization. The second generation in the main sphalerite mineralization is often accompanied by chalcopyrite inclusions or is surrounded by pyrite mineral or is sitting beside galena during growth (Figure 6(d), Figure 6(e), Figure 6(g) and Figure 6(m)).

Galena is the second economic mineral in Emarat deposit whose formation has occurred in the main mineralization stage simultaneous with sphalerite in its main and post mineralization stages. It lies in marginal surroundings of sphalerite and is often observed replaced by the sphalerite or in some sections it comprises the sphalerite or tennantite-tetrahedrite or pyrite and chalcopyrite minerals; the curved outcrops in this mineral shows mineralization before tectonization (Figure 6(d), Figure 6(f) and Figure 6(g)). It appears that galena mineralization is the last mineralization phase in the main stage of paragenetic sequence.

Pyrite was observed in various forms during all paragenetic sequence stages like pyrite with rounded or totally deformed margin, having been formed simultaneous with mineralization of galena and sphalerite (Figure 6(h) and Figure 6(e)); or cubic pyrite crystals (Figure 6(j)) on galena and sphalerite margins as well as euhedralpyrites in the host rock which have been formed before galena and sphalerite mineralization.

Chalcopyrite in sections is often seen adjacent to sphalerites or in fine inclusion forms and it seems like that it has been crystalized simultaneous with sphalerite in initial stages of main mineralization (Figure 6(k) and Figure 6(m)).

Covellite and chalcocite have been formed from dissolution of such minerals as chalcopyrite which belong to the final stages of sequence; tennantite-tetrahidrite often have been surrounded by sphalerite and galena which is indicative of formation of such minerals in the main stages of mineralization.

Quartz is the most frequently found gangue mineral in Emarat deposit which has been formed during pre- and post main mineralization stages (Figure 6(f) and Figure 6(m)). Quartz ore was observed in three different generations: 1) primary Mono-Crystalline quartz, constituting the matrix rock that has replaced the limestone during pre-mineralization stage, 2) Poly-Crystalline quartz which is the result of re-crystallization after diagenesis in pre-mineralization stage, and 3) quartz veinlets of main mineralization stage which are larger than the previous phase quartz, existing as the filler of open spaces and failures (Figure 6(a) and Figure 6(b)).

Calcite is one of the other gangue minerals of Emarat deposit which can be seen in two forms: The first type of calcite belonging to pre-crystallization and also pre-tectonic processes which are found with granular form and disseminate texture and the second type of calcite belonging to post-crystallization stage which has been re-crystalized after tectonic processes ruling the rock formation conditions and has penetrated in the rock in vein form (Figure 6(c)).

Regarding gangue minerals like quartz, calcite and dolomite it can be said that after settlement of carbonated host rock during diagenesis and post-diagenesis period, it has experienced considerable changes under dissolution, metasomatose, etc. processes, the most evident of which being dolomitization and silicification during paragenetic sequence.

Based on the findings resulting from mineralogy investigations using $X$ beam diffraction analysis (XRD), the sphalerite and galena ores were identified as the main ores, quartz, pyrite and serozite as the secondary ores, and gyps and smithsonite were identified as minorminerals (Figure 7 and Figure 8).

\section{Conclusions}

Based on the microscopic studies and the findings from $\mathrm{X}$ beam diffraction analysis, Emarat deposit features a simple mineralogy. The main metal ores include sulfide ores like sphalerite, galena, pyrite and chalcopyrite together with covelite and chalcozite, tennantite-tetrahydrite, smithsonite and serozite. The main gangue minerals in this deposit are quartz, calcite and dolomite and barite to a limited amount, having been formed between the shale and lime. 

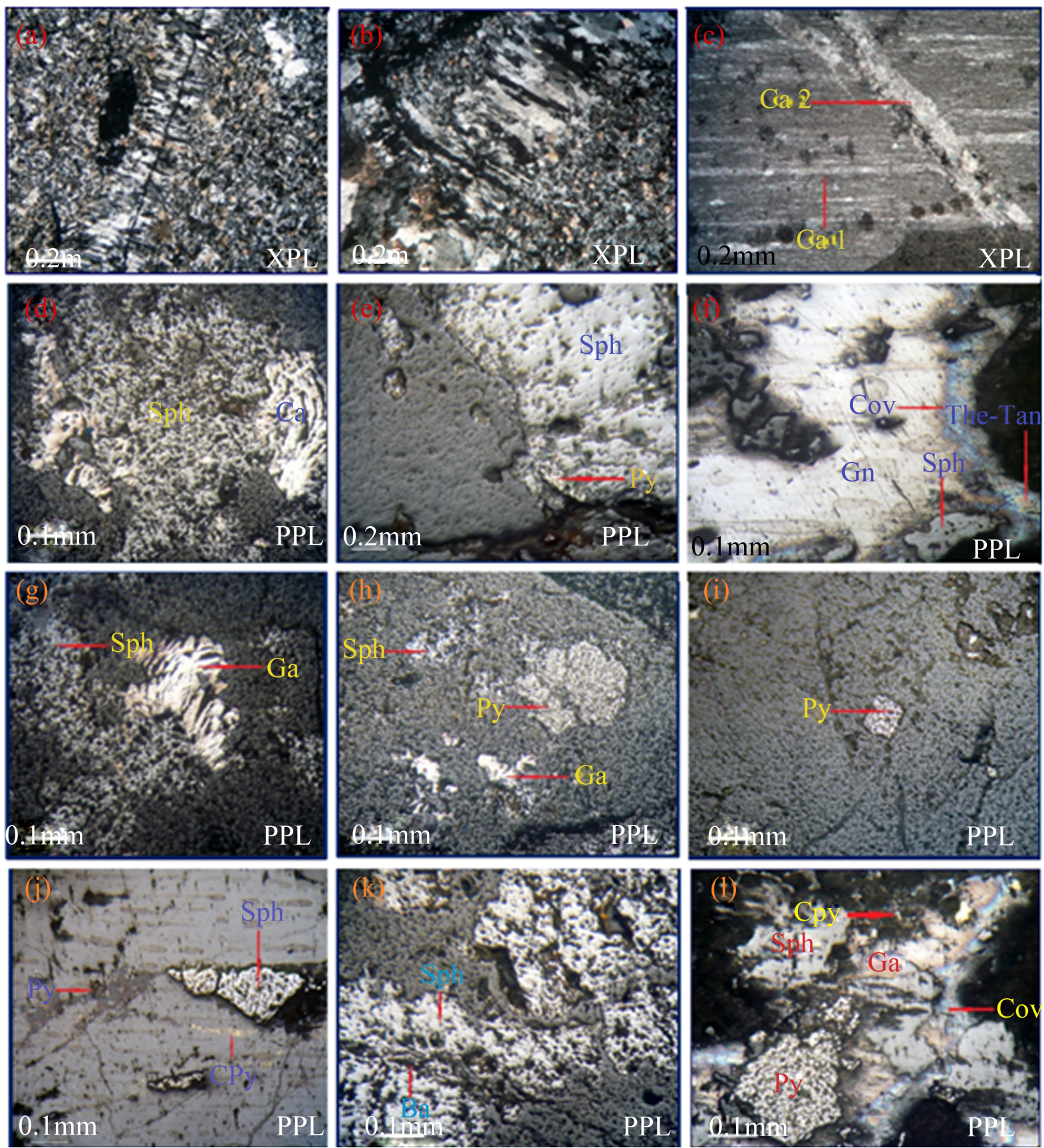

Figure 6. (a) Growth of quartz and calcite beside each other and fan texture formation; quartz crystals in 3 generations: 1) primary mono-crystalline quartz, 2) poly-crystalline quartz, 3) quartz veinlet in final stage, silica veinlet of syntaxial type; (b) Two types of silica veinlet: 1) elongated threadlike crystals; 2) re-crystalized silica veinlet; saw tooth contact between adjacent threads in quartz. (c) Orientation of the rock under the influence of tectonic pressures and two types of limestone veinlets: Type 1 (Ca1) before tectonic processes; Type 2: (Ca2) after tectonic processes. (d) Sphalerite ore with secondary replacement texture together with galena, bent under tectonic processes. (e) The sphalerite ore together with pyrite of disseminate texture and secondary replacement resulting from new mineralization stage. (f) Galena ore together with covelite and tennantite-tetrahedrite gangue ores surrounded by galena and sphalerite ore with secondary replacement texture. (g) Galena ore in sphalerite ore margin with bent faces $(\mathrm{h})$ Pyrite ore together with sphalerite ores and galena with disseminate texture. (i) Euhedral pyrite ore (j) Chalcopyrite ore together with pyrite and sphalerite ores with secondary replacement texture. (k) Sphalerite with secondary replacement texture resulting from a new mineralization stage has been replaced in sphalerite joints and breakages together with gangue ore (barite). (l) Chalcopyrite ore together with sphalerite, galena and pyrite and covelite gangue ore. 


\begin{tabular}{|c|c|c|c|}
\hline Mineral & $\begin{array}{l}\text { Pre Mineralization } \\
\text { Stage }\end{array}$ & Main Mineralization & Post Mineralization Stage \\
\hline Calcite & & & \\
\hline Dolomite & & & \\
\hline Quartz & & & \\
\hline Clay Minerals & & & \\
\hline Sphalerite & & & \\
\hline Galena & & & \\
\hline Pyrite & & & \\
\hline Chalcopyrite & & & \\
\hline Barite & & & \\
\hline Fe Oxides & & & \\
\hline $\begin{array}{l}\text { Covelite and } \\
\text { Chalcocite }\end{array}$ & & & \\
\hline $\begin{array}{l}\text { Tennantite- } \\
\text { Tetrahedrite }\end{array}$ & & & \\
\hline Smithsonite & & & \\
\hline Cerussite & & & \\
\hline
\end{tabular}

Figure 7. Paragenetic sequence of Emarat lead and zinc deposit.

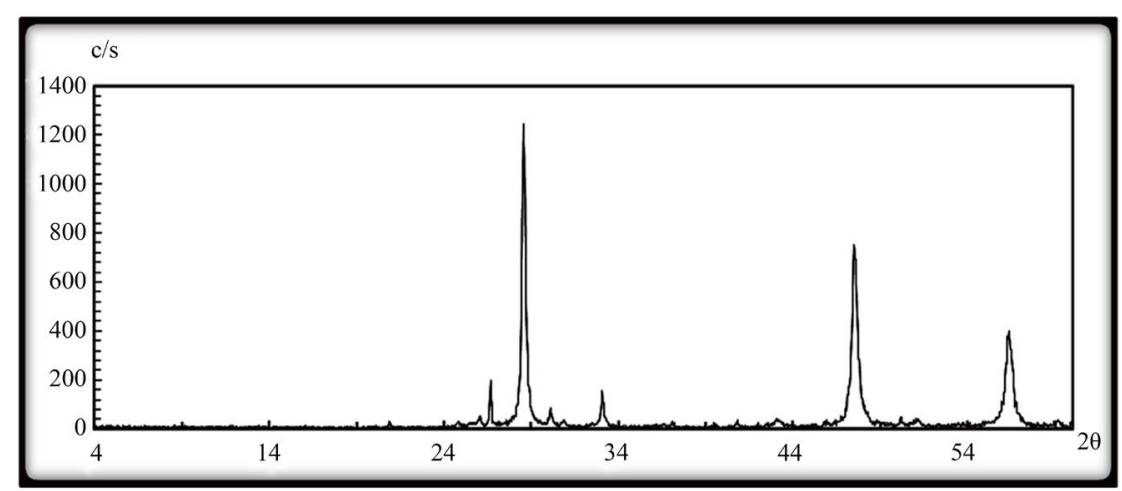

\begin{tabular}{|c|c|c|c|}
\hline Sample & Major Phase (s) & Minor Phase (s) & $\begin{array}{c}\text { Trace } \\
\text { Phase (s) }\end{array}$ \\
\hline EZCONC10 & $\begin{array}{c}\text { Sphalerite (05-0566) } \\
\text { ZnS }\end{array}$ & $\begin{array}{c}\text { Pyrite (06-0710) } \\
\mathrm{FeS}_{2}\end{array}$ & \multirow{7}{*}{--} \\
\hline AZ: 7580-31927 & & $\begin{array}{l}\text { Quartz (33-1161) } \\
\qquad \mathrm{SiO}_{2}\end{array}$ & \\
\hline Date: 02/02/2015 & & $\begin{array}{c}\text { Galena (05-0592) } \\
\text { PbS }\end{array}$ & \\
\hline $\mathrm{Kv}=40$ & & $\begin{array}{c}\text { Cerussite (05-0417) } \\
\mathrm{PbCO}_{3}\end{array}$ & \\
\hline \multicolumn{3}{|l|}{$\mathrm{mA}=30$} & \\
\hline \multicolumn{3}{|l|}{ Ka. $=\mathrm{Cu}$} & \\
\hline Fil. $=\mathrm{Ni}$ & & & \\
\hline
\end{tabular}

(a) 


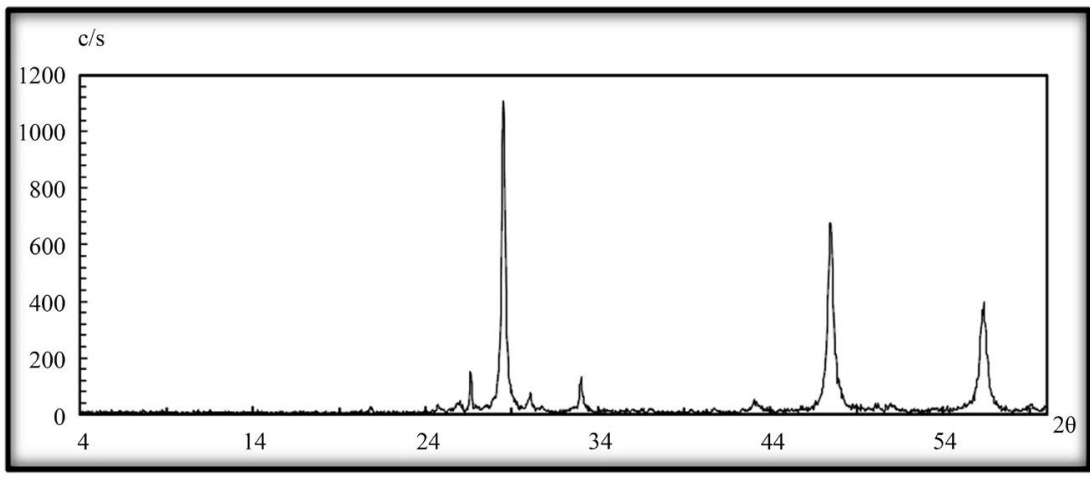

\begin{tabular}{cccc}
\hline Sample & Major Phase(s) & Minor Phase(s) & Minor Phase(s) \\
\hline \multirow{2}{*}{ EZCONC20 } & Sphalerite (05-0566) & Pyrite (06-0710) & Smithsonite (08-0449) \\
& ZnS & FeS $_{2}$ & ZnCO $_{3}$
\end{tabular}

\section{AZ: 7580-31929}

Date: 02/02/2015

$\mathrm{Kv}=40$

$\mathrm{mA}=30$

Ka. $=\mathrm{Cu}$

Fil. $=\mathrm{Ni}$
Quartz (33-1161) Albite (09-0466)

$$
\mathrm{SiO}_{2}
$$

$\mathrm{NaAlSi}_{3} \mathrm{O}_{5}$

Galena (05-0592) Orthoclase (31-0966)

$\mathrm{PbS}$

$\mathrm{KAlSi}_{3} \mathrm{O}_{8}$

Cerussite (05-0417)

$\mathrm{PbCO}_{3}$

(b)

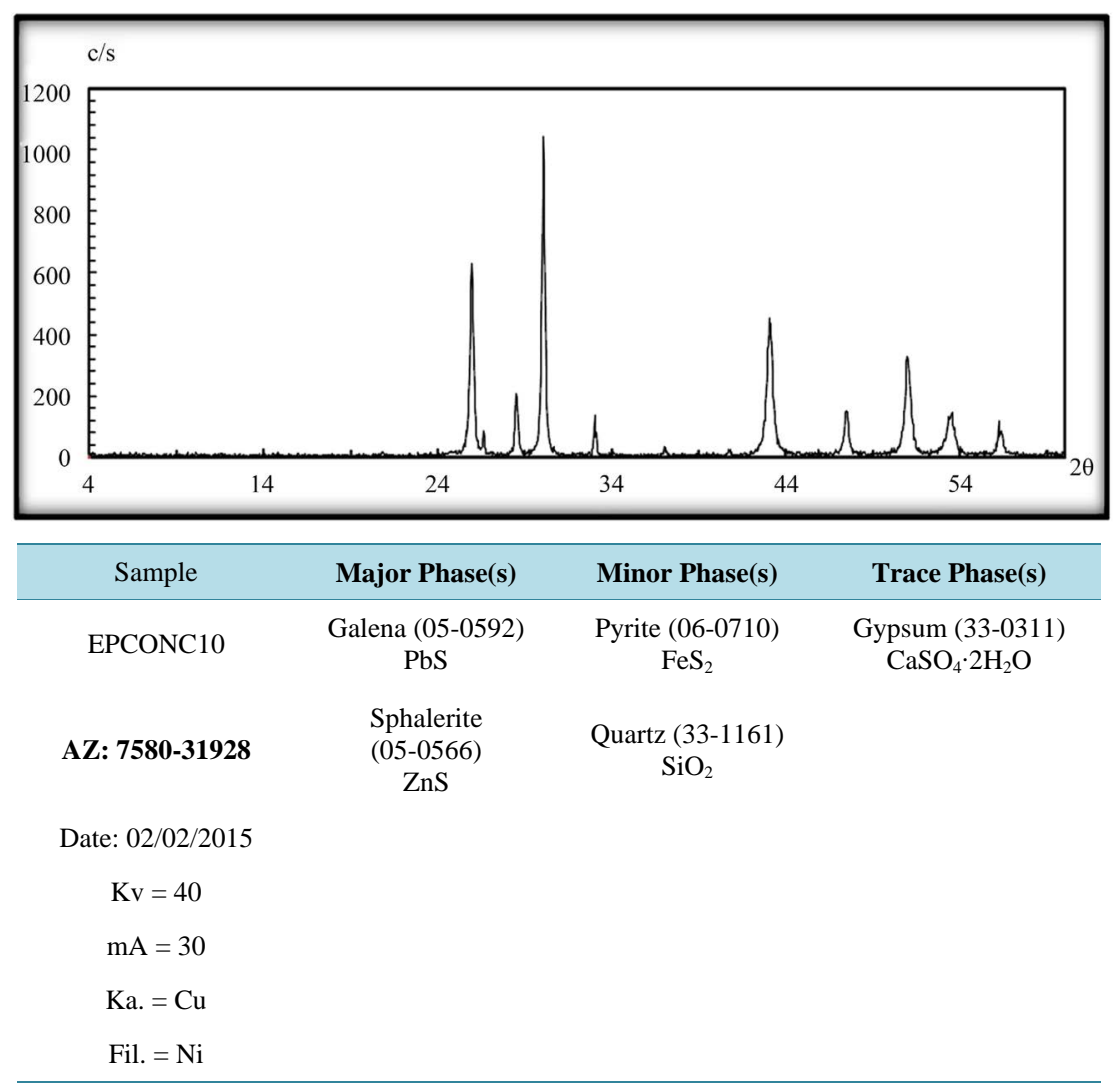




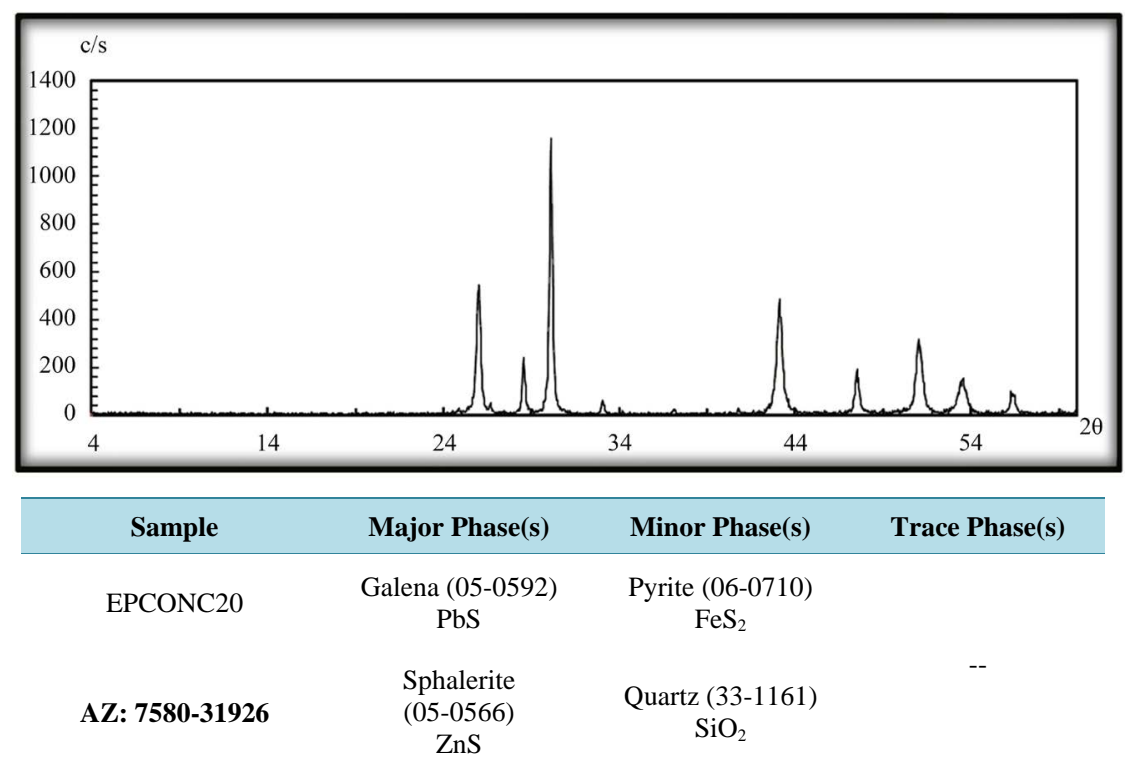

Date: 02/02/2015

$$
\begin{aligned}
\mathrm{Kv} & =40 \\
\mathrm{~mA} & =30 \\
\text { Ka. } & =\mathrm{Cu} \\
\text { Fil. } & =\mathrm{Ni}
\end{aligned}
$$

(d)

Figure 8. (a) The XRD analysis results of concentrated zinc sample showing thesphalerite, pyrite, quartz, galena and serozite ores. (b) XRD analysis results of concentrated zinc sample showing the sphalerite, pyrite, quartz, galena, serozite and smithsonite ores. (c) XRD analysis results of concentrated lead sample showing the sphalerite, pyrite, quartz, galena and gyps ores. (d) XRD analysis results of concentrated lead sample showing the sphalerite, galena, pyrite and quartz ores.

Sphalerite is the most abundant sulfide mineral. Mineralization in Emarat deposit is of open-space filling type. The mineral lies in discordant state and stratabound form with vein and veinlet outcrops together with silica alteration in upper section of K1 limestone unit and below Ks shale unit.

Silicification alteration is a major alteration in Emarat deposit and dolomitization, pyritization and hematitization were also observed in the deposit. Given the existing evidences it can be said that mineralization has occurred in post diagenetic stage and after tectonic influence and is of epigenetic type.

\section{Acknowledgements}

The Islamic Azad University provided facilities for this research for which the authors are grateful. We would like to acknowledge the Kansaran Binaloud Company for some data preparation.

\section{References}

[1] Adaabi, M. and Jamalian, M. (2007) Identifying the Primary Mineralogical Composition and Mineralization of Robat Carbonate Deposits (Khmeyn-Arak). Journal of Earth Sciences, No. 66, 23.

[2] Aqanbati (2004) Geology of Iran. Geological Survey of Iran, Tehran, 606 p.

[3] Aliabadi, M.A. (2000) Investigation of Geology, Mineralogy and Origin of Lead-Silver Ravnj of Delijan. MA Thesis, Shiraz University, Shiraz, 207 p.

[4] Ehya, F. (2009) Investigating the Sphalerite Geochemistry and Geothermometry in Emarat Lead and Zinc Deposit with Carbonated Host Rock. Journal of Applied Geology. 
[5] Faraji, K. (2009) Exploitation Plan of Emarat Lead and Zinc Deposit: A Report by Shahin. Industrial and Mining Company, Iran, 30 p.

[6] Fazli, S., Shamaniyan, GH. and Shafiei, B. (2011) Sulfur Isotopic Change in Sulphide Minerals of Emarat and Mouchan Lead and Zinc Deposits, Southwest of Arak. The First Congress on Economic Geology of Iran, Ferdowsi University of Mashhad, Khorasan Razavi.

[7] Ghazban, F., Mcnutt, R.H. and Schwarcz, H.P. (1994) Genesis of Sediment-Hosted Zn-Pb-Ba Deposits in the Irankuh District, Esfahan Area, West-CentralIran. Economic Geology, 89, 1262-1278. http://dx.doi.org/10.2113/gsecongeo.89.6.1262

[8] Krimpour, M.H. and Saadat, S. (2004) Applied Economic Geology. Mashhad University Press, Mashhad.

[9] Mohajjel, M., Fergusson, C.L. and Sahandic, M.R. (2003) Cretaceous-Tertiary Convergence and Continental Collision Sanandaj-Sirjan Zone, Western Iran. Journal of Asian Earth Sciences, 21, 397-412. http://dx.doi.org/10.1016/S1367-9120(02)00035-4

[10] Khosrow Tehrani, K. and Darvishzadeh, A. (1984) Geology for Experimental Sciences. Students and Teachers Training Centers, Tehran, $234 \mathrm{p}$.

[11] Momenzadeh, M., Shafighi, S., Rastad, E. and Amstutz, G.C. (1979) The Ahangaran Lead-Silvardeposit, SE-Malayer, West Central Iran. Mineralium Deposita, 3, 323-341.

[12] Momenzadeh, M. (1976) Stratabound Lead Zincores in the Lower Cretaceous and Jurassic Sediments in the MalayerEsfahan District (Westcentral Iran), Lithology, Metal Content, Zonationand Genesis. Ph.D. Thesis, Heidelberg University, Heidelberg, $300 \mathrm{p}$.

[13] Radfar, C. and Kohansal, R. (2004) 1: 100,000 Geologic Map of Arak. Geological Survey of Iran.

[14] Rahimpour-Bonab, H. (1991) A study of Southern Arak (Emarat) Lead and Zinc Deposits. MA Thesis, Tehran University, Tehran, 185 p.

[15] Rajbi, A., Rastad, E. and Canet, C. (2014) Metallogeny of Cretaceous Carbonate-Hosted Zn-Pb Deposits of Iran: Geotectonic Setting and Data Integration for Future Mineral Exploration. International Geology Review, 54, 1649-1672. http://dx.doi.org/10.1080/00206814.2012.659110

[16] Rajabi, A., Rastad, E. and Canet, C. (2012) An Introduction to Metallogeny of Permo-Triassic Carbonate-Hosted $\mathrm{Zn}-\mathrm{Pb}$ and F Deposits of Iran: Application for Future Mineral Exploration. Australian Journal of Earth Science, 60, 197-216. http://dx.doi.org/10.1080/08120099.2012.754792

[17] Salehi, L. (2004) Geochemistry of Trace Elements in Vishan-Tekyeh Lead and Zinc Deposit. MA Thesis, Shahid Beheshti University, Shahid Beheshti.

[18] Seyed Emami, K. (1971) The Jurassic Badamu Formation in the Kerman Region Remarks on the Jurassic Stratigraghy of Iran. Cont. Paleont. and Stratigraphy of Iran Part 1, Geological Survey of Iran Report, No. 19, 5-78 p.

[19] Thiele, O., Alavi, M., Assefi, A., Hushmand-Zadeh, A., Seyed-Emami, K. and Zahedi, M. (1968) Explantory Text of the Golpaygan Quadrangle Mapno. E7. Scale 1:250000. Geological Survey of Iran, 24.

[20] Venaie, M. (1998) The Structure, Texture and Geochemical Characteristics of Emarat-Arak Lead and Zinc Deposit. MA Thesis, Shahid Bahonar University of Kerman, Kerman, 168.

\section{Scientific Research Publishing}

\section{Submit or recommend next manuscript to SCIRP and we will provide best service for you:}

Accepting pre-submission inquiries through Email, Facebook, Linkedin, Twitter, etc

A wide selection of journals (inclusive of 9 subjects, more than 200 journals)

Providing a 24-hour high-quality service

User-friendly online submission system

Fair and swift peer-review system

Efficient typesetting and proofreading procedure

Display of the result of downloads and visits, as well as the number of cited articles

Maximum dissemination of your research work

Submit your manuscript at: http://papersubmission.scirp.org/ 